\title{
Material Culture as a Source for Writing the History of a School: a Brazilian Example
}

\author{
Eurize Caldas Pessanha (Corresponding author) \\ Human Sciences Center, Universidade Federal de Mato Grosso do Sul \\ Rua São Paulo, 526, apt 901 \\ Campo Grande - Mato Grosso do Sul \\ CEP 79010-050, Brazil
}

Tel: 55-67-3324-3087

Fabiany de Cássia Tavares Silva

Universidade Federal de Mato Grosso do Sul, Brazil

E-mail: fabiany@uol.com.br

Received: August 21, 2012

Accepted: May 24, 2013

Published: May 25, 2013

doi:10.5296/jse.v3i2.2277

URL: http://dx.doi.org/10.5296/jse.v3i2.2277

\begin{abstract}
This paper presents and discusses theoretical-methodological questions that are raised regarding the collection, classification, and analysis of information found in documents and photographs. These questions are related to an extensive research project whose goal was to write a middle school's history based on its material supports. These material supports-the buildings and the organization of their spaces, furniture, equipment and tools, books, notebooks, and other objects used in schools - enable a material culture approach for analyzing a school's meaning and purpose. Based on Grosvenor's proposal in 1999 and the Ginzburg's historiographical operation of hunting, we attempted to visualize the past of the Maria Constança Barros Machado School, a Brazilian secondary school from the 1930s in Brazil's Central Region. From administrative reports that had been prepared to demonstrate that the school was adequately equipped and had permission to offer courses, we selected four laboratory photographs. These photographs clearly indicate that the school had the material objects required by law to obtain operational authorization. This study may be relevant to researchers investigating the materiality of education history because the findings clearly express the theoretical inquiries that we often encounter, particularly questions related
\end{abstract}


to the conceptual aspects of material culture.

Keywords: Education, Secondary school, Culture, Material culture, Brazil 


\section{Objectives and purposes}

Our inquiry is related to the history of curricula, and we sought material support using that history along with other sources as trails to create a more inclusive view of actual events (Hobsbawm, 1994). Based on the proposal of Grosvenor (1999), we attempted to visualize the past in a Brazilian secondary school from the 1930s using photographs that show objects related to the educational practices of the school.

The history of the Maria Constança Barros Machado School has been linked to the educational and modernizing projects of Campo Grande, a strategic city in the south of Mato Grosso, Brazil. Created in the late 1930s as Liceu Campograndense, this school was the first government secondary school that was developed for students who could not afford to pay the costs of attending a private institution. However, the school was also highly selective. Among other reasons, the competitive nature of the entrance exam (exame de admissão) rendered it an exemplary school. Since the school's genesis, its exemplarity has been promoted by the social groups who considered themselves part of the elite when they were admitted to the school (Silva \& Pessanha, 2008).

Schools in other Brazilian cities have reported similar educational practices. The history of the education of the urban population in Brazil appears to have produced a number of exemplary schools at the end of the $19^{\text {th }}$ century. Exemplary schools were not specifically created to serve as a model for other schools, although their potential for serving this purpose should not be rejected.

The history of this school shows how the city educates its citizens, at least those belonging to a certain social group at a certain point in time. In other words, these exemplary schools express projects of modernization and of the education of specific groups.

Some groups from the middle class have considered education to be an effective strategy for pursuing social mobility, a parallel process integrated into the expansion of urban development. In every urban development project, the school was regarded as a strategic place to demonstrate the city's modernity. By all accounts, each city intended to have its own school; this school would not be merely any school but the school that would represent the identity of the city (Pessanha \& Daniel, 2002; Silva \& Pessanha, 2012)

The lack of objects from the past that would, even today, enable an analysis of material supports in the educational process forces researchers investigating the history of the material culture of the school to base their work on references to school objects in administrative writings.

In our detailed study of four schools situated in four Brazilian cities, we sought to establish the relationship between the history of these cities and their schools. We concluded that in each of these cities, the educational project was linked to urban development.

The oldest school considered in our research was Liceu de Humanidades de Campos, founded in 1880 in a city dating from the $17^{\text {th }}$ century. By the middle of the $18^{\text {th }}$ century, this city was considered the richest and most populous of all cities in Rio de Janeiro (Faria, 2001), where the planting, harvesting, and trading of sugar cane occurred. The newest school considered in our study, Maria Constança School, was established in 1939, and its history is linked to a city that arose in a different period, Campo Grande, the city that emerged from the cattle (Bittar, 
2004). The two other schools are Grupo Escolar Conde Parnahyba, which was founded in 1906 in Jundiaí, a city whose history is connected to the growing of coffee and to the railroads, and Ginásio Mineiro, which was founded in 1912 in Uberlândia, a city whose development was encouraged by wholesale trading.

The Maria Constança Barros School, a secondary school that was created in a city in the interior of midwestern Brazil in the 1940s and 1950s, shows the exemplary nature of its school culture by the following characteristics:

- The selectivity of students admitted (i.e., the school was intended for only a few students);

- The level of expectations: pupils from less demanding schools would have difficulty succeeding in the courses at this school;

- The teachers' level of excellence: the school selected a real teacher who viewed their work at the school as an honor;

- $\quad$ The respect for teachers exhibited by pupils that some people believe should resemble a type of worship;

- $\quad$ Prominent buildings, true monuments, selective teachers, and pupils who were members of an elite group, and former pupils and former teachers in distinguished positions that allowed these actors to express the school culture of these exemplary schools, thus providing pupils and teachers with Bourdieu's cultivated habitus (2007).

The goal of this research project was to prepare an outline of the curricular history of a secondary school using material objects that constitute the evidence and vestiges of this history from 1939 to 1970 . This work was to be performed by comparing the information acquired by examining the iconography, uniforms, objects, furniture, equipment, and school utensils in the documented sources-those that had previously been inventoried and analyzed—using space and time as analysis categories.

\section{Theoretical framework}

Our research on the schooling process in Brazil begins with the supposition that school culture is clearly expressed in its material supports: the mediating tools of the educational action and structural elements for the school operation (Souza, 2007). These material supports - the buildings and the organization of their spaces, furniture, equipment and tools, books, notebooks, and other objects used in schools - enable a material culture approach for analyzing the purposes and meanings of a school.

The Journal of Material Culture (SAGE publication), which is dedicated to this subject, has been in existence since 1996, and there are also conferences and research centers that address material culture. Researchers in this field are interested in all possible objects of a historical period. A brief review of the published papers in the previously mentioned journal reveals a wide range of studies of objects and periods, including houses, tampons and sanitary towels, books, letters, coffee tables, rugs, masks, windsurfing supplies, clothes, cards, jars, Hello Kitty objects, washing machines, semen donor containers, photographs, puppets, Batman figurines, Barbie dolls, objects for the teaching of mathematics, television sets, glass bottles, graves, trees, jeans, murals, radios, stones used in Candomblé rituals, warships, fashion, 
detritus from industrial ruins, landscapes, architecture, sarongs, talismans, rubbish, monuments, air conditioning equipment, food, and movies. ${ }^{1}$

In this paper, we worked with the notion and idea of material culture (Bucaille \& Pesez, 1989), which incorporated the polysemy of the term culture (Williams, 1981). The notion of material culture, a term with origins in the second half of the $19^{\text {th }}$ century, was first recognized institutionally in a decree by Lenin in 1919 that created an institution, the Akademiia Istorii Material'noi Kul'turv, to study the history of material culture (Bucaille \& Pesez, 1989).

According to the editor of the American Historical Review, many historians are examiners of a manqué material culture because they do not consider the inherent interdisciplinary character of these studies (Auslander, Bentley, Halevi, Sibum, \& Witmore, 2009).

Our research addressed the perception that in the analysis of the history of education, tension has existed between aspects that are primarily related to society (macro) and those that are primarily related to school practices (micro).

Attempts to articulate both of these dimensions led us to Carlo Ginzburg's indiciary paradigm, which considers to whom the historical knowledge is indirect, indiciary and conjectural (Ginzburg, 1992), in a historiographic operation of hunting, in which we search for trails that allow for the differentiation of the universal from the particular.

With regard to terminology, we chose to use the expression materialities of the school culture, which solves the contradiction that may arise from the expression material culture and indicates interest in objects as clues to school culture, as referenced in Ginzburg's indiciary paradigm.

\section{Methods}

The search for clues that allow for the reconstruction of the history of a particular school implies a historiographic operation that is different from an analysis of documents; this operation, as promoted by Ginzburg, may be called a hunting operation (Ginzburg, 1992), i.e., hunting for the material supports of this history.

Considering beyond the hunting operation, we attempted to rebuild the connections between singular occurrences using signs, clues, trails, and particular cases without abandoning the notion of the historical totality, as determined by Hobsbawm (1994), who viewed historical knowledge, as a particular field of human knowledge, as essentially changeable and always temporary.

In the relatively new research field of Brazilian education history, efforts to find documentable sources coexist with attempts to preserve the memories of schools. In this process, the site of objects related to school practices led to investigations that considered these objects to be forms of material support for the process of education in Brazil. Believing that this material support can provide information regarding the life of a school during a particular period, we essentially transformed these objects into documents.

\footnotetext{
${ }^{1}$ Data are obtained from http://mcu.sagepub.com.
} 
To paraphrase Leonora Auslander in an AHR conversation ${ }^{2}$ (Auslander et al., 2009), our objective is not to understand the changes in curricular history but to understand how these changes emerged and what they can teach us about the curricular history of the schools because it was the schools themselves that selected, purchased, and used these objects as material support for their practices.

Research in curriculum history within the limits of our object of study is determined by the prospect of reconstructing the history of an institution from a particular version by analyzing documents, establishing relationships and correlations to rebuild a network of meanings of or related to school culture, and rereading each document in an attempt to reconstruct the daily curriculum. The starting point for this effort was the idea that this work involves performing tasks that are complex, diffuse, and difficult to capture and that reveal what was or is obscured and determined.

When attempting to perform this reconstruction, we reaffirm the tension between the macro-social aspects and dimensions of micro-schools in which the curriculum is reified. However, we must first reduce our analysis of these aspects, i.e., the material culture from the perspective of portraying the curriculum space as a space for the dissemination of a speech and for the formalization and consolidation of identities. This reduction in understanding is anchored in the sense that societies and (more specifically) schools give to objects, documents, and artifacts to identify the brand gifts as an expression of the multiple experiences of the production, reproduction, and appropriation of cultures. It is assumed that the curriculum is surrounded by the idea that culture is selected (i.e., that choices are made in a broad universe of possibilities and that culture is considered a space in which meanings are produced.

To write the history of Maria Constança Barros Machado School (founded in 1939), the historiographical operation of hunting (Ginzburg, 1992) included administrative reports related to the most remarkable moments of the school's history in the 1940s, 1950s, and 1960s as well as lists of materials and photographs of laboratories showing these materials.

In Brazil, all schools require governmental permission to operate. The authorization process has varied according to the historical period but has always included visits from a government representative who would evaluate the conditions of the school and write a report either authorizing the operation of the school or not consenting to such operation.

As vestiges of the history of the school, we analyzed documents related to the creation, establishment, and legalization of the school as Liceu Campograndense. These documents included the Previous Inspection Report of 1941, which was required to obtain permission to operate the ginásio (middle school); the 1956 Verificative Report, establishing the second level (high school equivalent); and documents from the Conselho Estadual de Educação (State Council of Education) related to the regularization of the first grade school in 1977.

\footnotetext{
${ }^{2}$ My goal was not to understand shifts in furniture styles but rather to understand how those variations arose and what we could learn about the people who had imagined, crafted, sold, purchased, and used these products (p. ) and what we could discover in their institutions. (p. 1371)
} 


\section{Macrothink}

Journal of Studies in Education

ISSN 2162-6952

2013, Vol. 3, No. 2

\section{Results}

Detailed lists of materials and equipment for the physics, chemistry, and natural history laboratories were also found; these lists were detailed and long to the extent that they received a grade of 10 and were accompanied by comments from the inspector.

These lists correspond to the equipment that schools were required to have and that are listed in the Administrative Directive (number 501) for May 19, 1952: Chapter XXII - The School's Furnishings (Brasil, 1956, p. 210).

In the School Memorandum Book, there is one entry with the title Opening and Examination of Material, which indicates that the physics, chemistry, geography, and English teachers collaborated on September 13, 1940 to open nine volumes containing the objects to be used by the departments of physics and chemistry, natural history, geography, physical education, and drawing (Termo de abertura e exame de material. Livro de Atas, 1939 (Pessanha \& Assis, 2011). These materials were purchased from companies in São Paulo and Rio de Janeiro: Franz Sturm \& Cia Ltd., 115, Bonifácio St., São Paulo; Empreza Progresso Ltd., in Rio de Janeiro, 49, Dom Geraldo St.; and Brasileira Fornecedora Escolas Ltd., I São Paulo, 791, São João Avenue (Pessanha \& Assis, 2011).

From these documents, we selected four photographs whose titles refer to the laboratories:. Physics Laboratory (Figure 1); Chemistry Laboratory (Figure 2); Natural History Laboratory (Figure 3) and Laboratory (Figure 4).

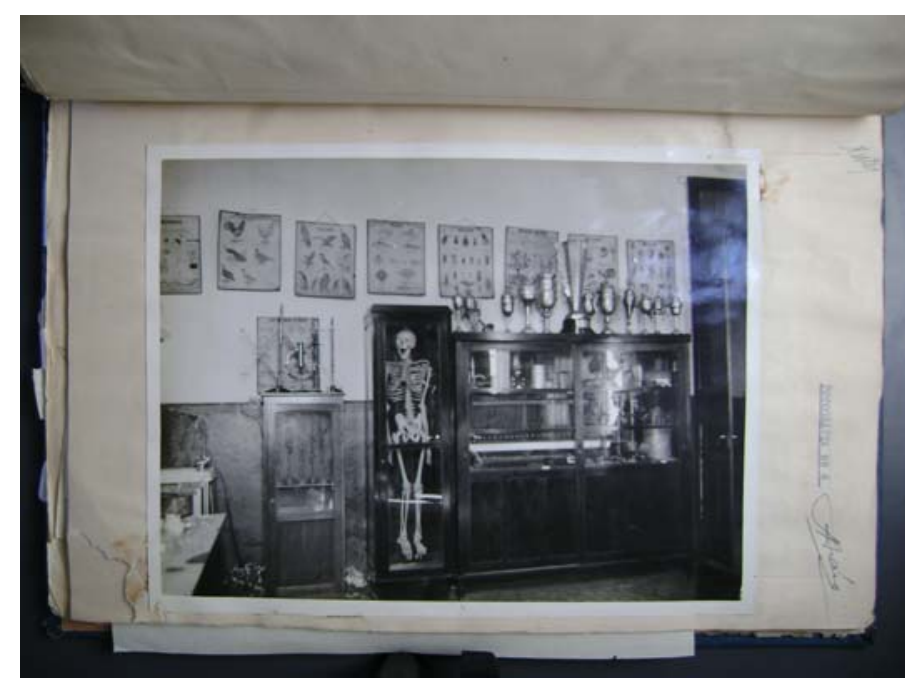

Figure 1. Physics Laboratory

Photograph from the 1956 Report (Pessanha \& Assis, 2011) 


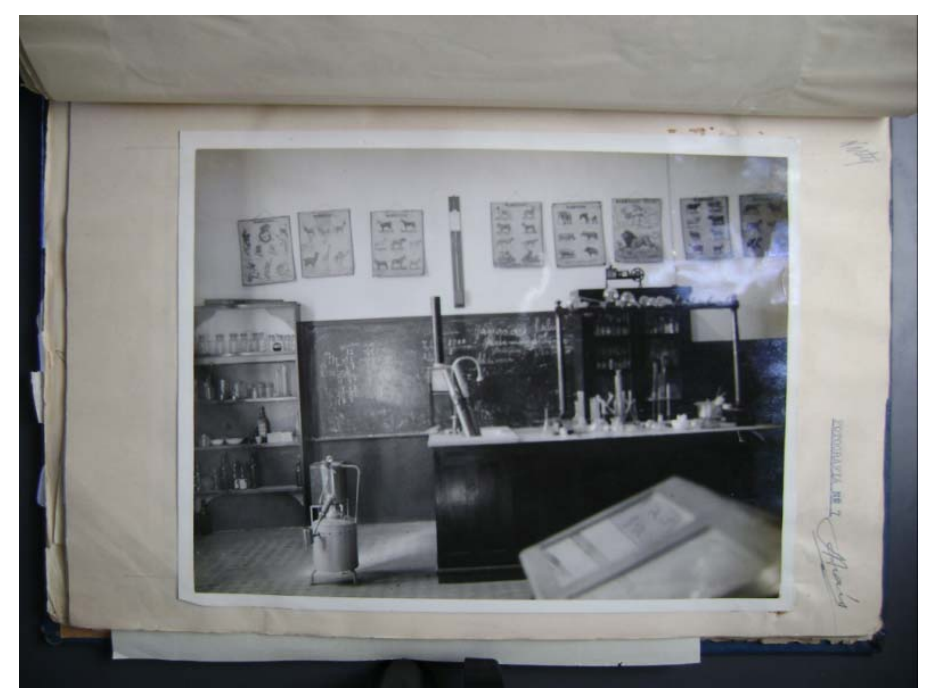

Figure 2. Chemistry Laboratory

Photograph from the 1956 Report (Pessanha \& Assis, 2011)

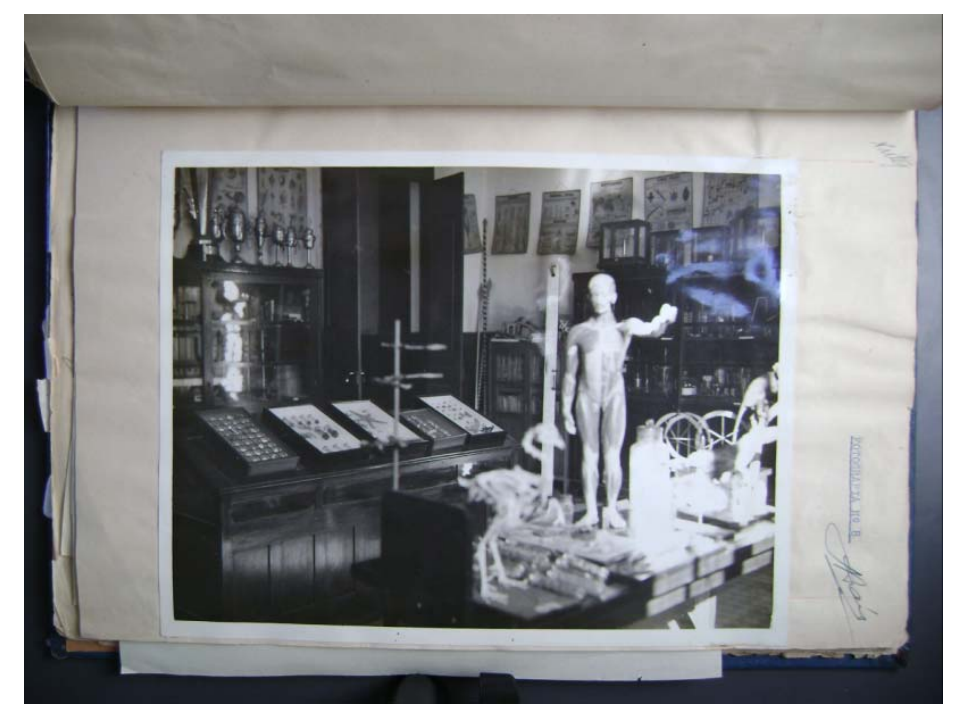

Figure 3. Natural History Laboratory

Photograph from the 1956 Report (Pessanha \& Assis, 2011) 


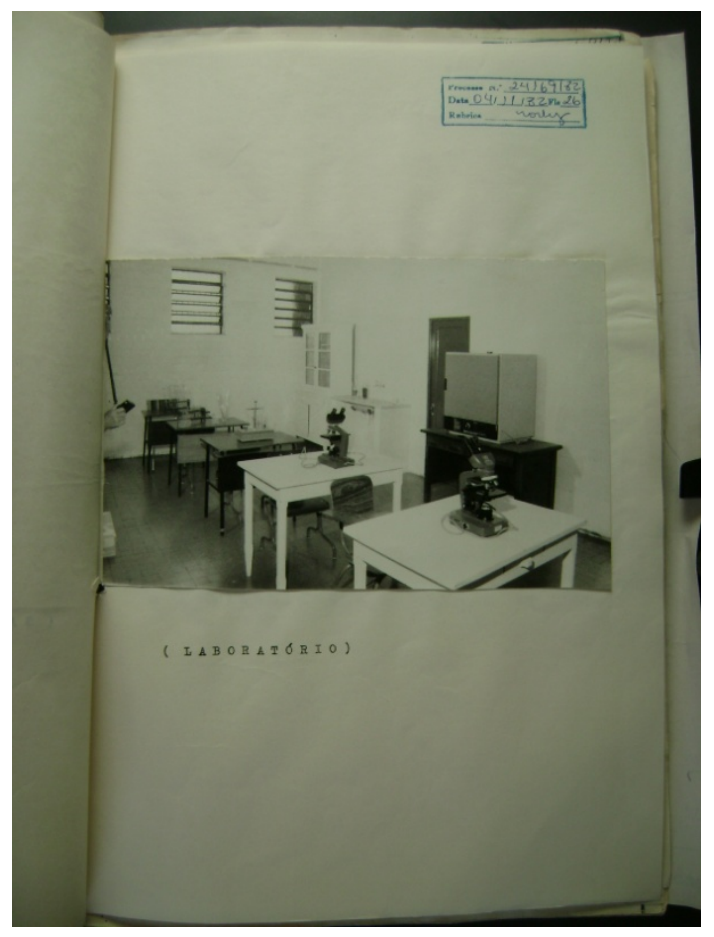

Figure 4. Laboratory

Photograph from the 1977 Report (Pessanha \& Assis, 2011)

The first three photographs, identifying the physics, chemistry, and natural history laboratories, present different views of the same environment, each showing equipment related to the respective subject: a room with cupboards, equipment, glassware, scales, a skeleton, a human body, and stone and animal collections. The fourth photograph is from a 1977 report and shows a room with tables and chairs, microscopes, a sterilizer, and a cupboard.

By comparing the photograph documents, we were able to verify that the laboratories were equipped with the materials required by the curriculum.

The first three photographs refer to the first phase: the founding of the school in the 1940s and the founding of the second level of the secondary school in the 1950s. During this period, under Lei Orgânica do Ensino Secundário (the Organic Law of the secondary school) (Brasil, 1952), the school was expected to maintain collections as well as an apparatus for measuring and weighing, as determined by national legislation. The apparatus was an expression of scientific education, a prevailing concept until the 1950s, when education was based on the collection and exhibition of objects (as in a museum); however, there was no indication that these apparatuses were used by students or teachers.

Although there was a blackboard in the room and the lists were separated into Demonstration and Experiment, the photographs from the 1940s show a room full of objects that could not have been used by the pupils or teachers. 
The fourth photograph, from the 1970s, presents a technical conception of education under the 5692/1971 law and provides clues that the scientific conception recommended for that period was intended to include opportunities for students to obtain hands-on experience, as demonstrated by the sufficient space and furniture visible in the photograph.

If the goal of the abovementioned reports was to demonstrate and prove that the school was adequately equipped and had obtained permission to offer the courses that it intended to provide, then the photographs left no doubt that the school actually possessed the material objects that would be required by law to obtain the necessary permission. Therefore, we may conclude that the photographs fulfilled their function to provide testimony and empirical evidence, thereby removing doubt and subjective interpretation and helping the school verify that the necessary standards had been achieved.

\section{Discussion}

This study may be relevant to researchers investigating the materiality of the history of education because it clearly expresses the theoretical inquiries that we encounter (i.e., questions related to the conceptual aspects of material culture). From one perspective, the European theoretical source links the origin of this field to the political options and to the attention given to the material life. In contrast, the North American source, which began with the anxiety of collecting and securing objects, has only recently begun to follow a direction similar to the European source.

This approach leads us to a line of inquiry that researchers of material objects encounter in terms of the distinction between a text-thing whose cultivation is considered essential to scholars and a material culture.

Although the simplistic definitions of material culture being related to things versus traditional historiography pertaining to texts can be rejected, the expression material culture does not appear to be appropriate because-apart from being a contradiction in terms if we consider the common distinction that considers culture in opposition to material-the expression concerns culture, a word that is one of the most difficult words in the English language according to Williams and whose polysemous character transfers its weight to the expression material culture.

Here, we have presented the results of a study whose goal was to write the curricular history of a school using Ginzburg's indiciary paradigm based on clues provided by the material support of this history.

The photographs that have been presented here offer an initial approach to these clues and constitute a wider approach to the material support than the administrative writings do; however, the reliance on photographs in the historiographical process to reveal the school's past provokes new theoretical-methodological questions.

As testimony, photographs have documentary status: they present empirical evidence and generate doubt and subjective interpretation by the audience and thus become less compelling. First, it is important to recall that the photographs were conceived as printed eye-witness 
accounts of the facts: the photographs were objective witnesses, neutral or mirrors of nature that followed the laws of nature without the intervention of the human hands, thereby achieving the status of reliable and unquestionable documents. Analyzing a photograph is not a simple task. As Grosvenor (1999) noted, G. Clarke considers photographs to be part of "writing with light" (p. 85 \& 87) and explains that the comparison of light to writing raises peculiar inquiries. In the end, it is not possible to treat a photograph as a written text that has been created using a different tool.

Grosvenor asks a basic question regarding the reading of classroom photographs: What is the relation between the classroom and the photographer's creative lens? Although such photographs are "a bridge between the past and the present" (Grosvenor, 1999, p. 86), this bridge can also entrap a historian who, conscious of the informative status of the documents, may be induced to equate the photographs with historical truth because of the closeness to the past that they appear to bear. As clues, photographs of objects do not end inquiries about them, for one could further pose questions as to who selected the objects to be photographed and how they were selected, acquired, and used.

As Magalhães (2004) warned, it is necessary to proceed from a document to memory as well as from memory to document. The analysis of photographs cannot be separated from the analysis of the history of the institution in which they were produced.

With respect to the school studied here, one may conclude that all of the photographs were produced with the intent of their inclusion in the official administrative document of school and were circulated among those who were involved with the inspection, authorization, and recognition processes required by law. Thus, the photographs serve the function of testimony and empirical evidence by excluding subjective interpretations and individual doubts and thereby assisting the school in obtaining the necessary authorization for its opening.

\section{Acknowledgement}

Thanks are given to Universidade Federal de Mato Grosso do Sul and to CNPq (National Council for Scientific and Technological Development) for the financial support.

\section{References}

Auslander, L., Bentley, A., Halevi, L., Sibum, H. O., \& Witmore, C. (2009). AHR conversation: Historians and the study of material culture. American Historical Review, 114, 1355-1404. http://dx.doi.org/10.1086/ahr.114.5.1355

Bittar, M. (2004). Dos campos grandes à capital dos ipês: Parte I. Campo Grande, Brazil: Gráfica Editora Alvorada.

Bourdieu, P. (2007). A distinção: Crítica social do julgamento. São Paulo, Brazil: Edusp.

Brasil. (1952). Exposição de motivos da Lei Orgânica do Ensino Secundário, de $1^{\circ}$ de abril de 1942. In Ensino secundário no Brasil (pp. 22-28). Rio de Janeiro, Brazil: Ministério da Educação e Saúde. Instituto Nacional de Estudos Pedagógicos.

Brasil, Ministério da Educação e Cultura. (1956). Lei Orgânica do Ensino Secundário e 
Legislação Complementar. Rio de Janeiro, Brasil: Departamento de Imprensa Nacional.

Bucaille, R., \& Pesez, J. M. (1989). Cultura material. In R. Betti (Ed.), Enciclopédia Einaudi 16, 11-47. Lisbon, Portugal: Einaudi.

Faria, T. P. (2001). Projeto de modernização e mudança da morfologia social e urbana de Campos dos Goytacazes, Rio de Janeiro, nos anos 1870-1880. Anais do IX Encontro Nacional da Anpur, 1, 785-796.

Ginzburg, C. (1992). Clues, myths and the historical method. (J. Tedeschi \& A. C. Tedeschi, Trans.). Baltimore, MD: Johns Hopkins University Press.

Grosvenor, I. (1999). On visualizing past classrooms. In I. Grosvenor, M. Lawn, \& K. Rousmaniere (Eds.), Silences and Images. The social history of the classroom. New York, NY: Peter Lang Publishing.

Hobsbawm, E. (1994). Age of extremes: The short twentieth century 1914-1991. London, England: Michael Joseph.

Magalhães, J. P. (2004). Tecendo nexos: história das instituições educativas. Bragança Paulista, Brazil: Editora Universitária São Francisco.

Pessanha, E. C., \& Assis, W. S. (2011). Arquivos digitalizados da Escola Estadual Maria Constança Barros Machado (Campo Grande/MS). Campo Grande, Brazil: W. S. Assis.

Pessanha, E. C., \& Daniel, M. E. B. (2002). História da cultura escolar através dos exames: O caso dos exames de admissão ao Ginásio (1931-1971). Intermeio: Revista do Mestrado em Educação, 8, 4-15.

Silva, F. C. T., \& Pessanha, E. C. (2012). Observations of school culture: From theorists to curriculum issues. International Education Studies, 5, 65-70. http://dx.doi.org/10.5539/ies.v5n4p65

Silva, F. C. T., \& Pessanha, C. E. (2008). Professores e alunos compondo a história de uma instituição exemplar no sul do Mato Grosso (1939-1950): A Escola Maria Constança Barros Machado. In V Congresso Brasileiro de História da Educação (pp. 1-11). Aracaju, Brazil: SBHE.

Souza, R. F. (2007). História da cultura material escolar: Um balanço inicial. In M. L. Bencostta (Ed.), Culturas escolares, saberes e práticas educativas: Itinerários históricos (pp. 163-189). São Paulo, Brazil: Cortez.

Williams, R. (1981). Culture, Fontana New Sociology Series. Glasgow, Scotland: Collins. 